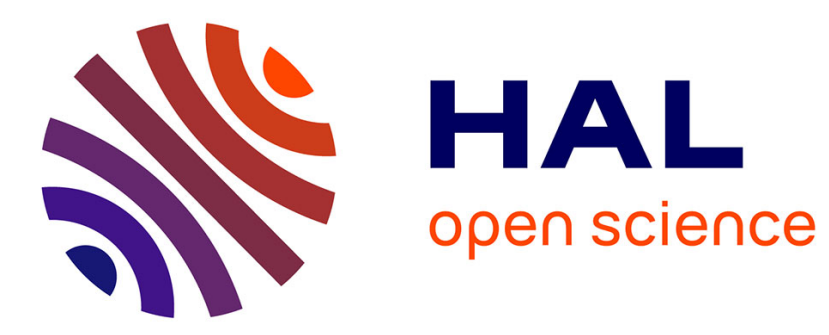

\title{
Pollen-based biome reconstructions over the past 18,000 years and atmospheric CO2 impacts on vegetation in equatorial mountains of Africa
}

Kenji Izumi, Anne-Marie Lézine

\section{- To cite this version:}

Kenji Izumi, Anne-Marie Lézine. Pollen-based biome reconstructions over the past 18,000 years and atmospheric CO2 impacts on vegetation in equatorial mountains of Africa. Quaternary Science Reviews, 2016, 152, pp.93 - 103. 10.1016/j.quascirev.2016.09.023 . hal-01382682

\section{HAL Id: hal-01382682 \\ https://hal.sorbonne-universite.fr/hal-01382682}

Submitted on 17 Oct 2016

HAL is a multi-disciplinary open access archive for the deposit and dissemination of scientific research documents, whether they are published or not. The documents may come from teaching and research institutions in France or abroad, or from public or private research centers.
L'archive ouverte pluridisciplinaire HAL, est destinée au dépôt et à la diffusion de documents scientifiques de niveau recherche, publiés ou non, émanant des établissements d'enseignement et de recherche français ou étrangers, des laboratoires publics ou privés. 
1 Pollen-based biome reconstructions over the past 18,000 years and atmospheric $\mathrm{CO}_{2}$

2 impacts on vegetation in equatorial mountains of Africa

3 Izumi, K. ${ }^{1,2}$, Lézine, A.-M. ${ }^{3}$

$4{ }^{1}$ Laboratoire de Météorologie Dynamique, IPSL, CNRS, Université Pierre et Marie Curie, 4 5 place Jussieu, 75005 Paris, France

$6 \quad{ }^{2}$ Laboratoire des Sciences du Climat et de l'Environnement, CNRS-CEA-UVSQ, Université

7 Paris-Saclay, Gif-sur-Yvette cedex 91191, France

$8{ }^{3}$ Sorbonne Universités, UPMC, Paris 06 Université, CNRS-IRD-MNHN, Laboratoire 9 LOCEAN/IPSL, 4 place Jussieu, 75005 Paris, France 


\section{Abstract}

11 This paper presents a quantitative vegetation reconstruction, based on a biomization

12 procedure, of two mountain sites in the west (Bambili; $5^{\circ} 56^{\prime} \mathrm{N}, 10^{\circ} 14^{\prime} \mathrm{E}, 2273 \mathrm{~m}$ ) and east

13 (Rusaka; 3²6' S, 29³7' E, $2070 \mathrm{~m}$ ) Congo basin in equatorial Africa during the last 18,000

14 years. These reconstructions clarify the response of vegetation to changes in climate,

15 atmospheric pressure, and $\mathrm{CO}_{2}$ concentrations. Two major events characterize the biome changes

16 at both sites: the post-glacial development of all forest biomes ca. 14,500 years ago and their

17 rapid collapse during the last millennium. The rates of forest development between the biomes

18 are different; a progressive expansion of lowland biomes and an abrupt expansion of montane

19 biomes. The trends of pollen diagrams and biome affinity scores are not always consistent in

20 some periods such as the Younger Dryas interval and end of the Holocene Humid Period,

21 because the biomization method is not a simple summarization of the pollen data, but also takes

22 biodiversity into consideration.

23 Our sensitivity experiment and inverse-vegetation modeling approach show that changes

24 in atmospheric $\mathrm{CO}_{2}$ concentration unequally influence vegetation in different local

25 environments. The study also suggests that the biome changes prior to the Holocene result from

26 both changes in the atmospheric $\mathrm{CO}_{2}$ concentration and climate. The development of warm-

27 mixed forest from xerophtic vegetation results from increases in atmospheric $\mathrm{CO}_{2}$ concentration

28 and near-surface air temperature. Difference in local dryness results in the different biome

29 distributions, with more forest-type biomes at Bambili and more grass/shrub-type biomes at

30 Rusaka.

\section{1. Introduction}


33 the viewpoint of their great floral and faunal diversity, they must have been in existence over the

34 last several million years even though their extent could have fluctuated with climate and

35 atmospheric composition. However, some previous palaeoecological studies (e.g., Maley and

36 Brenac, 1998; Vincens et al., 1999; Runge, 2002; Lézine et al., 2013a, b; Desjardin et al., 2013)

37 show that the equatorial forest ecosystems in Africa have undergone drastic modifications

38 (floristic, structural and palaeogeographic) in response to climate changes since the last glacial

39 maximum (LGM, ca. 21,000 years ago, $21 \mathrm{ka}$ ). These modifications include the possible

40 fragmentation of equatorial forested communities (Maley, 1996), the expansion of species

41 restricted to high elevations today (Dupont et al., 2000) at the LGM and the collapse of the

42 forests around 4-2 ka (Vincens et al., 1999; Lézine, 2007; Marchant and Hooghiemstra, 2004;

43 Lézine et al., 2013a,b). Changes in plant distribution and abundance from the last glacial

44 onwards were also observed in the lowlands all over North Africa, from the Equator to the

45 Northern Tropic (e.g., Lézine et al., 2009; Watrin et al., 2009; Hély and Lézine, 2014).

46 Moreover, ${ }^{13} \mathrm{C}$ measurements on leaf waxes implied the replacement of tropical montane forest

47 by scrub vegetation, the downward migration of alpine treelines and the marked shift towards

48 C4-plant dominance in the tropics during the last glacial period (e.g., Street-Perrott et al., 1997;

49 Huang et al., 1999).

50 Climate factors, such as moisture and heat are commonly invoked to explain the changes

51 in ecosystem composition and structure (e.g., Lézine et al., 2011; Anadón et al., 2014). Other

52 factors, such as atmospheric pressure and atmospheric $\mathrm{CO}_{2}$ could potentially also have some

53 impacts on the vegetation through physiological processes. Reduced partial pressure of $\mathrm{CO}_{2}$ and

$54 \mathrm{O}_{2}$ associated with an increase in altitude related to lower sea level during glacial times could 
55 influence photosynthesis (e.g. Friend and Woodward, 1990; Terashima et al., 1995; Sakata and

56 Yokoi, 2002). A decrease in atmospheric $\mathrm{CO}_{2}$ generally results in a reduction of in the

57 abundance of plants with C3-photosynthesis pathway because of the required increased rates of

58 photorespiration, and an expansion of C4-plants due to their adaptation anatomically and

59 physiologically to low atmospheric $\mathrm{CO}_{2}$ concentrations (e.g., Ehleringer et al., 1997; Cowling

60 and Sykes, 1999). Simulations with the BIOME3 equilibrium vegetation model also indicated

61 that low atmospheric $\mathrm{CO}_{2}$ alone could result in the observed replacement of tropical montane

62 forest by scrub vegetation at the LGM (Jolly and Haxeltine, 1997). To understand vegetation

63 changes at tropical high-elevation sites in paleoecological context, we therefore need to

64 understand the effect of changes in the atmospheric $\mathrm{CO}_{2}$ concentration and air pressure to the

65 vegetation as well as purely climatic effects.

66 In this study we focus on changes in biomes at roughly similar altitude (2000 2300 m) in

67 tropical Africa: to the West in the Cameroon volcanic line (Bambili) and to the East in the Kivu

68 montane range (Rusaka). Detailed pollen studies at both sites (Lézine et al., 2013a; Bonnefille et

69 al., 1995) have shown that vegetation composition varied considerably through time from $18 \mathrm{ka}$

70 to the present. The goals of our paper are 1) to discuss biome changes in these mountain areas

71 over the past $18 \mathrm{ka}$ and 2) to investigate the impacts of changes in atmospheric $\mathrm{CO}_{2}$

72 concentration on vegetation at the early in the last deglaciation (i.e., $18 \mathrm{ka}$ ) using an inverse

73 vegetation-modeling approach. The comparison between two distant sites will enable us to

74 identify the more prominent climate-change events that have affected the Afromontane forests.

\section{2. Equatorial mountains of Africa}

\section{$76 \quad 2.1$ Geographical features}


The Cameroon volcanic line is a crescent-shaped chain of highlands and volcanoes that

78 extends from the Gulf of Guinea to the Southwest to the Adamawa plateau to the Northeast.

79 Mean altitude decreases from West (around $2000 \mathrm{~m}$ in the "Grassfield" region) to East (around

$801000 \mathrm{~m}$ in the Adamawa plateaus), punctuated by high mountains, such as Mount Cameroon on

81 the coastline (4095 $\mathrm{m}$ ) and Mount Oku in the Western plateaus (3011 m). Bambili is a crater lake

82 located in the Western plateaus $\left(05^{\circ} 56^{\prime} \mathrm{N}, 10^{\circ} 14^{\prime}\right.$ E, $2273 \mathrm{~m}$; Figure 1) close to Mount Oku

83 where the Afromontane forest is preserved today (Letouzey, 1968, 1985; Momo Solefak, 2009).

84 Regional precipitation, with the rainy season from March to October, is due to the West African

85 monsoon. The temperature is lower relative to lowlands over the tropical Africa due to the

86 altitude of the site.

87

88

89

90

91

92

93

94 branch of the East African Rift, following a roughly North-South direction. The mountain ranges

95 include high mountains, such as the Virunga Mountains (4507 m) and the Rwenzori Mountains

$96(5109 \mathrm{~m})$. These altitudes are not reached in Burundi where the highest peak reaches $2684 \mathrm{~m}$

97 only. Rusaka is a swamp lying at $3^{\circ} 26^{\prime} \mathrm{S}, 2^{\circ} 37^{\prime} \mathrm{E}$ and $2070 \mathrm{~m}$ in altitude (Figure 1). The 
98 regional climate of Rusaka is related to the South African monsoon, the rainy season is from

99 November to May.

\subsection{The African biomes}

Fossil pollen data are generally expressed in the form of abundances of individual plant

102 taxa, and detailed pollen descriptions at Bombili and Rusaka have been provided elsewhere

103 (Bonnefille et al., 1995; Lezine et al., 2013). The pollen sequence is continuous and extends from

1040 to 18,071 years ago at Bambili and extends from 750 to 18,061 years ago at Rusaka. Here we

105 use biomes, which are geographically and climatically broadly distributed physiognomic

106 vegetation types, for representing vegetation changes in this study. The biomes are represented

107 by assemblages of plant functional types (PFTs) that are defined on the basis of plant traits (e.g.,

108 the life form, leaf form, phenology, and bioclimatic tolerances) that reflect their preferable

109 environments, in which the species maximize productivity and minimize environmental stress

110 (Table 1). The use of biomes and PFTs helps to solve the problem of classifying paleoecological

111 records by reducing the number of entities considered and by proving an ecological basis for

112 treating plants from different regions in a comparable way. A method for converting pollen taxa

113 to biomes (i.e. biomization) is described in section 3.1.

114 Table 1. Plant functional types proposed for the west and east African areas PFT

\begin{tabular}{cl}
\hline te & Tropical evergreen \\
tr1 & Wet tropical raingreen \\
tr2 & Dry tropical raingreen \\
tr3 & Driest tropical raingreen \\
sf & Steppe forb/shrub \\
df & Desert forb/shrub
\end{tabular}


wte1 Warm-temperate broad- and needle-leaved evergreen (higher elevation)

wte2 Warm-temperate broad- and needle-leaved evergreen (lower elevation)

c3a C3 herb from lowlands areas at the boundary between the Saharan and the Mediterranean zones

c3b C3 herb from the afroalpine grasslands (top of the mountains $>2800 \mathrm{~m}$ alt)

c4 C4 herb (tropical grasslands and savannas)

115

116 The Afromontane vegetation of Africa is discontinuous, with patches separated from one

117 other by lowlands, and thus is referred to as the "Afromontane archipelago" (White, 1983).

118 Despite the geographic discontinuity, they share numerous plant species that are distinct from the

119 surrounding lowland regions. Three main biomes (Table 2), common to all Afromontane regions,

120 are distinguished. They correspond to an elevation gradient from roughly $1600 \mathrm{~m}$ to the top of

121 the highlands:

122 - Warm mixed forest (WAMF) occurs in a lower ombrophilous areas and in the lowland 123 Guineo-Congolian forests;

124 - Afro-alpine forest (AAF) occurs in an areas at higher elevation typically above $2000 \mathrm{~m}$,

125 with upper limit of the forest is typified by the presence of abundant Ericaceae; and

126 - Afro-alpine grassland (AAG) is cool afro-alpine grasslands that consist of C3 grasses

127 which are found neR the top of the mountains above $2800 \mathrm{~m}$.

128 Regional differences between the eastern and western mountain ranges are observed, however,

129 with e.g., Hagenia, Clifforita, Afrocrania and Junioerus absent from the western sector

130 (Cameroon), as well as Artemisia that has never been collected here. 
131 Table 2. West and east African biomes and their characteristic plant functional types (PFTs), 132 main phytogeographical affinities and main vegetation types (White, 1983)

\begin{tabular}{|c|c|c|c|}
\hline Biomes & PFTs & main phytogeographical affinities & main vegetation types (main taxa $*$ ) \\
\hline AAG & $\mathrm{c} 3 \mathrm{~b}$ & $\begin{array}{l}\text { Afromontane archipelago-like centre of } \\
\text { endemisms (VIII) }\end{array}$ & $\begin{array}{l}\text { Afromontane udifferentiated montane vegetation (C3 } \\
\text { grasses mainly Poaceae, Alchemilla, Asteraceae) }\end{array}$ \\
\hline AAF & wte1 & $\begin{array}{l}\text { Afromontane archipelago-like centre of } \\
\text { endemisms (VIII) }\end{array}$ & $\begin{array}{l}\text { Afromontane udifferentiated montane vegetation } \\
\text { (Podocarpus, Prunus, Syzygium, Nuxia, Rapanea, } \\
\text { Maesa, Myrsine, Hagenia, Juniperus, Hypericum, } \\
\text { Ericaceae) }\end{array}$ \\
\hline WAMF & wte2 & $\begin{array}{l}\text { Afromontane archipelago-like centre of } \\
\text { endemisms (VIII) }\end{array}$ & $\begin{array}{l}\text { Afromontane udifferentiated montane vegetation } \\
\text { (Podocarpus, Ilex, Schefflera, Syzygium, Olea, } \\
\text { Strombosia, Ficus, Celtis, Rutaceae, Sapindaceae, } \\
\text { Euphorbiaceae) }\end{array}$ \\
\hline TRFO & te & $\begin{array}{l}\text { Guineo-Congolian regional center of } \\
\text { endemism (I) }\end{array}$ & $\begin{array}{l}\text { Lowland rain forest: wetter types (Caesalpiniaceae, } \\
\text { Mimosaceae, Moraceae, Meliaceae, Irvingiaceae) }\end{array}$ \\
\hline TSFO & $\operatorname{tr} 1$ & $\begin{array}{l}\text { Guineo-Congolian regional centre of } \\
\text { endemism (I)/ } \\
\text { Guineo-Congolian/Sudanian/Zambezian } \\
\text { regional transition zone }(\mathrm{XI})\end{array}$ & $\begin{array}{l}\text { Lowland rain forest: drier types / mosaic of lowland } \\
\text { rain forest and secondary grassland / Swamp forest } \\
\text { (Ulmaceae, Sterculiaceae) }\end{array}$ \\
\hline TDFO & $\operatorname{tr} 2$ & $\begin{array}{l}\text { Sudanian (III)/Zambezian (II) regional } \\
\text { centre of endemism }\end{array}$ & $\begin{array}{l}\text { Woodland / dry forest / Miombo (Brachystegia, } \\
\text { Julbernardia, Isoberlinia, Combretaceae, Lannea, } \\
\text { Prosopis, Hallea, Monotes, Protea, Euphorbiaceae.) }\end{array}$ \\
\hline SAVA & $\begin{array}{l}\operatorname{tr} 3+\mathrm{c} \\
4\end{array}$ & $\begin{array}{l}\text { Southern Sahel regional transition zone } \\
\text { (XVI)/Guineo- } \\
\text { Congolian/Sudanian regional transition } \\
\text { zone (XI) - Zambezian transition zone } \\
\text { (X)/Lake Victoria mosaic (XII) }\end{array}$ & $\begin{array}{l}\text { Wooded grassland/ deciduous bushland/ mosaic of } \\
\text { lowland rain forest and secondary grassland (C4 tall } \\
\text { (up to } 3 \mathrm{~m} \text { high) grasses, Terminalia, Lophira, } \\
\text { Mitragyna inermis, Borassus aethiopium) }\end{array}$ \\
\hline STEP & $\mathrm{sf}+\mathrm{c} 4$ & $\begin{array}{l}\text { Northern Sahel regional transition zone } \\
\text { (XVI)/Somalia-Masai regional centre of } \\
\text { endemism (IV) }\end{array}$ & $\begin{array}{l}\text { Semi-desert grassland and shrubland (C4 short } \\
\text { grasses, Acacia, Commiphora, Balanites, } \\
\text { Capparidaceae) }\end{array}$ \\
\hline DESE & $\begin{array}{l}\mathrm{df}+\mathrm{c} 4 \\
+\mathrm{c} 3 \mathrm{a}\end{array}$ & Sahara regional transition zone (XVII) & $\begin{array}{l}\text { Desert (C4 short grasses, } \\
\text { Chenopodiaceae/Amaranthaceae, Resedaceae, } \\
\text { Brassicaceae) }\end{array}$ \\
\hline
\end{tabular}

* Pollen nomenclature follows Vincens et al. (2007). 
138 and South) tropical dry forests (TDFO), to a mixture of woodlands and grasslands (i.e. savanna

139 (SAVA)), to the Sahelian (to the North)/Somalia Masai (to the East) steppes (STEP), and finally

140 to desert (DESE).

141 In this study, we focus on nine biomes (three biomes for highlands and six biomes for

142 lowlands) on the basis of our own field expertise and local descriptive botanical literature

143 (Troupin, 1982; Letouzey, 1968, 1985; Momo Solefak, 2009).

\section{3. Methods}

\section{$145 \quad 3.1$ Biomization procedure}

146 Biomization is a quantitative procedure that reconstructs biomes on the basis of the

147 characteristic signature in the pollen record of different PFTs (Prentice and Webb, 1998). There

148 are five steps in the biomization method used here: (1) assignment of taxa represented in the

149 pollen assemblages to PFTs (i.e., defining a taxon $\times$ PFT matrix), (2) definition of biomes as

150 combinations of PFTs (defining a PFT $\times$ biome matrix), (3) combination of the above two

151 matrices (defining a taxon $\times$ biome matrix by simple matrix multiplication of the matrices from

152 steps 1 and 2), (4) for a particular pollen assemblage, calculation of affinity scores for each

153 biome, and (5) selection of a biome with the highest affinity score as the dominant biome

154 represented by that pollen assemblage. The detailed formula for step 4 is described in Prentice

155 and Webb (1998). The affinity score for each biomes can be thought of as a measure of the likely

156 presence at a site of that biome given the particular pollen spectrum, such that the lower affinity

157 the score, the less likely the biome is to be present. The score is not equivalent to the proportion

158 of the area covered by an individual biome at the site, but simply describes presence or absence. 
160 and past biomes for selected time periods, typically the last glacial period and the Holocene (e.g.

161 Prentice et al., 2000; Elenga et al., 2000; Jolly et al., 1998a). Within tropical Africa, the method

162 has been applied to modern pollen samples at the continental scale (Jolly et al., 1998) or more

163 regionally in East (Vincens et al., 2006) and West Africa (Lézine et al., 2009). Past biome

164 reconstructions have also been performed for Plio-Pleistocene (Bonnefille et al., 2004; Novello

165 et al., 2015) and more recent (from the last glacial to the present) sections (Lebamba et al., 2012;

166 Amaral et al., 2013).

167 We have used the complete matrices, pollen taxa-PFTs-biomes for both Bambili and 168 Rusaka defined by Vincens et al. (2006) and Lézine et al. (2009), respectively, and the PFTs169 biomes matrix (Table 1,2) is the same for both sites. The lakeshore aquatic plant taxa and ferns 170 taxa were removed as these respond to local hydrological conditions, rather than being reflective

171 of broader scale climate controls. While a $0.5 \%$ threshold for all taxa has generally been used in

172 calculating affinity scores to reduce the incidence of misassignment among relatively species-

173 poor assemblages (Prentice and Webb, 1998), we selected $0.2 \%$ threshold for this study after an

174 examination of several biomization practices. We also used a threshold (40\%) for Poaceae in 175 order to minimize the over-representation of this taxon in individual pollen spectra.

\section{$176 \quad 3.2$ A sensitivity experiment for a simple $\mathrm{CO}_{2}$ effect on vegetation}

177 In order to explore the impact of change in atmospheric $\mathrm{CO}_{2}$ alone on vegetation at 178 Bambili and Rusaka, we first performed a sensitivity experiment. The experimental design is 179 similar to the one in Jolly and Haxeltine (1997); the observed seasonal climate data is held 180 constant and only atmospheric $\mathrm{CO}_{2}$ concentration is varied (from $400 \mathrm{ppm}$ to $180 \mathrm{ppm}, 10 \mathrm{ppm}$ 
181 interval) for running two coupled biogeography and biogeochemical models, BIOME5-beta

182 (Izumi, 2014) and BIOME4 (Kaplan et al., 2003). These models simulate common equilibrium

183 vegetation and bioclimatic variables, but they have different vegetation responses to change in

184 atmospheric $\mathrm{CO}_{2}$ concentration (e.g., BIOME5-beta has lower carbon use efficiency, the ratio of 185 net primary production to gross primary production). In running these vegetation models, we use

186 monthly climate from CRU CL 2.0 (New et al., 2002) and soil (FAO, 1995) at each site.

187 Altitude-adjusted air pressure is used at each site $\left(7.7 \times 10^{4} \mathrm{~Pa}\right.$ at Bambili and $7.9 \times 10^{4} \mathrm{~Pa}$ at 188 Rusaka).

$189 \quad 3.3$ Inverse-modeling through an iterative forward modeling approach

190 In order to examine the potential impacts of altitude and changes in atmospheric $\mathrm{CO}_{2}$

191 concentration on vegetation from the viewpoint of pollen-based climate reconstruction, we used

192 an "inverse modeling through iterative forward modeling" (IMIFM) approach (Izumi 2014;

193 Izumi and Bartlein, in revision), which can be compared with the forward modeling approach

194 that uses inputs of climate and $\mathrm{CO}_{2}$ concentrations to mechanistically simulate vegetation. The

195 IMIFM approach (also called "inverse vegetation modeling" approach for climate reconstruction

196 in Guiot et al. (2000) and Wu et al. (2007a)), was developed to overcome some disadvantages of

197 conventional statistical reconstruction approaches, such as modern-analogue, regression, and

198 response-surface techniques. These conventional approaches generally require several ecological

199 assumptions for climate reconstruction from pollen data, in particular that climate is the ultimate

200 cause of change in vegetation, and the modern data contain all the information necessary to

201 interpret the paleodata (Guiot et al., 2009). However, plant-climate interactions are very sensitive

202 to atmospheric $\mathrm{CO}_{2}$ concentration (e.g., Cowling and Sykes, 1999; Prentice and Harrison, 2009) 
203 and thus modern pollen samples influenced by higher $\mathrm{CO}_{2}$ concentrations of the past century are

204 not necessarily good analogs for climates under lower $\mathrm{CO}_{2}$ concentrations.

The basic assumption of the IMIFM approach is that it should be possible to reconstruct

206 the climate data that gave rise to a "target" paleovegetation sample by searching for the set of

207 climate scenarios, which input to a forward vegetation model yields a simulated vegetation that

208 resembles the vegetation represented by a target fossil-pollen sample. The application of the

209 IMIFM approach involves the generation of many thousands of candidate sets of individual

210 climate-variable values that are individually discarded or retained depending on their ability to

211 correctly generate the observed vegetation using a specific forward model. The retained climate-

212 variable values, which allow a correct simulation of the target vegetation, are then statistically

213 summarized to provide the reconstructed or estimated values of the climate variables.

214 The IMIFM approach has the potential to provide more accurate quantitative climate

215 estimates from pollen records than statistical approaches because it allows the mechanistic

216 effects of non-climatic variables, such as the atmospheric $\mathrm{CO}_{2}$ concentration and atmospheric

217 pressure, to be explicitly considered in the reconstruction. However, the approach is strongly

218 dependent on the quality of the forward vegetation model. Therefore, to reduce the dependency

219 of our results on a single model, we use two equilibrium vegetation models, BIOME5-beta and

220 BIOME4. The detailed methodology and vegetation models consulted for individual papers.

221 In the IMIFM approach for climate reconstruction, we need to compare pollen-based

222 observed biomes with the simulated biomes in the vegetation models. We define the simulated

223 biomes as follows: the afro-alpine forest (AAF) is composed of simulated scrubland and mixed

224 forest, and the afro-alpine grassland (AAG) is the simulated temperate grassland, but the climate 
225 spaces for both $\mathrm{AAF}$ and $\mathrm{AAG}$ are based on the climatic requirements of temperate

226 microphyllous shrub vegetation (i.e., the minimum mean temperature of the coldest month

227 (MTCO) is $5{ }^{\circ} \mathrm{C}$, and the maximum of the MTCO is $10.5^{\circ} \mathrm{C}$ ) in Jolly et al. (1998b). The climate

228 spaces for simulated warm mixed forest (WAMF) are based on BIOME4's description of

229 WAMF, but the minimum of MTCO is increased to $10.5^{\circ} \mathrm{C}$. Below that threshold in MTCO the

230 simulated biome is regarded as AAF. In searching the climate scenarios over the deep tropical

231 areas, we allow for differences between mean temperature of the warmest month (MTWA) and

232 MTCO of less than $7^{\circ} \mathrm{C}$.

233 In order to investigate the effects of changes in atmospheric $\mathrm{CO}_{2}$ concentration to climate

234 spaces of a target biome (i.e., AAF at Bambili and AAG at Rusaka) at the early in the last

235 deglaciation (i.e., $18 \mathrm{ka}$ ), we set two experiments using the IMIFM approach at each site; exp. 1)

236 paleo atmospheric $\mathrm{CO}_{2}$ concentration (194 ppm for ca. $18 \mathrm{ka}$; Bazin et al., 2013) and exp. 2)

237 modern atmospheric $\mathrm{CO}_{2}$ concentration (331 ppm). The difference between exp. 1 and exp. 2

238 shows the effects of atmospheric $\mathrm{CO}_{2}$ difference to the target biome. In running these vegetation

239 models, we use monthly climate from CRU CL 2.0 (New et al., 2002) and soil (FAO, 1995) at

240 each site. Altitude-adjusted air pressure is used at each site $\left(7.7 \times 10^{4} \mathrm{~Pa}\right.$ at Bambili and $7.9 \times$

$24110^{4} \mathrm{~Pa}$ at Rusaka).

\section{4. Results}

\section{$243 \quad 4.1$ Vegetation changes}

244 First, we present summary pollen diagrams showing percentages of the three main pollen

245 groups: trees, herbs and undifferentiated (which correspond to pollen grains determined at a too

246 low taxonomic level and/or pollen grains corresponding to plants with a variety of life forms) in 
247 order to illustrate the main physiognomical changes (i.e., ratio between trees and herbs) over the

248 last $18 \mathrm{ka}$ at Bambili and Rusaka (Figure 2a-b). Both sites have varying degrees of vegetation

249 change, but the pollen percentages show some common trends between the two sites over the last

$25018 \mathrm{ka}$; a progressive expansion of forests over the last glacial-interglacial transition period, in

251 particular during the Bølling/Allerød warm period (ca. $13.8 \mathrm{ka}$ ) and the Holocene, and

252 degradation of the forests during the Younger Dryas interval (ca. 12.9 to $11.7 \mathrm{ka}$ ), and at ca. 8.2

$253 \mathrm{ka}, 3.3 \mathrm{ka}$, and $1.2 \mathrm{ka}$.

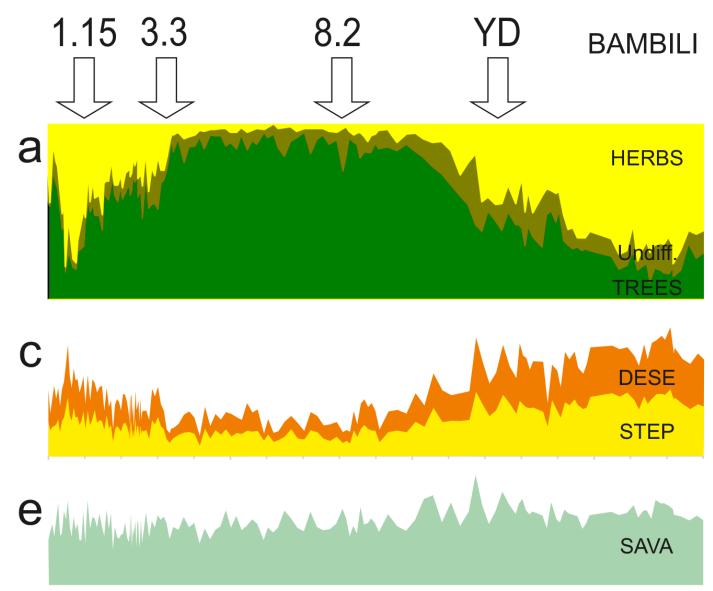

9
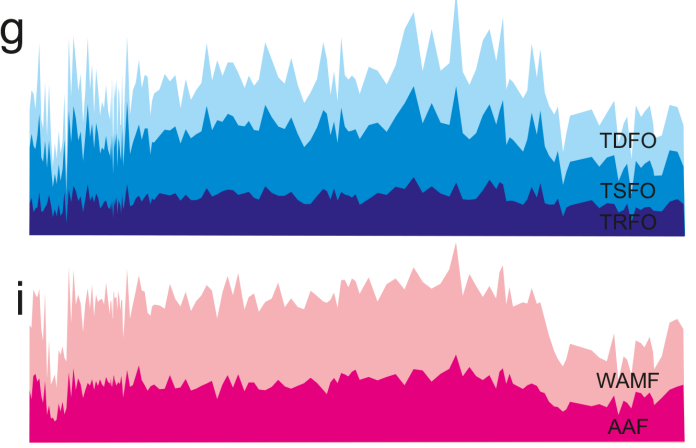

\section{$\mathrm{k}$}

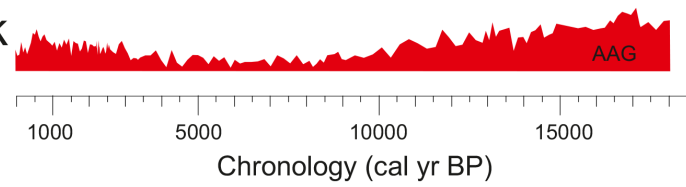

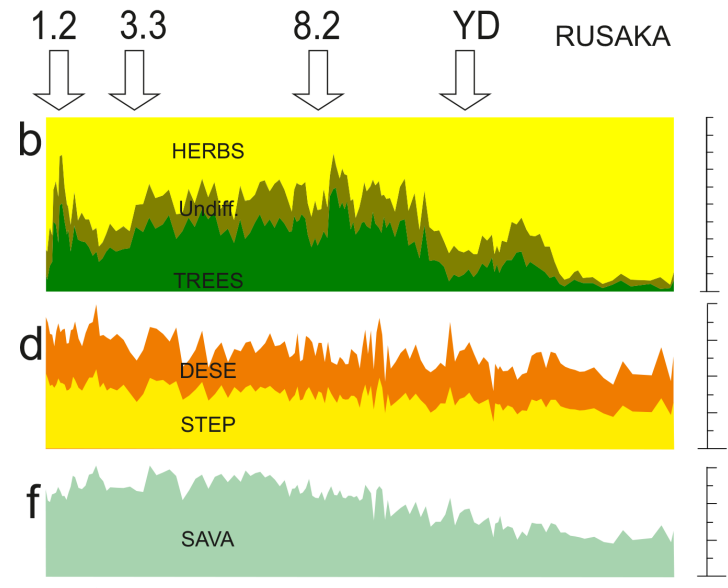

100
80
60
40 을
20 유

40

20

30

15

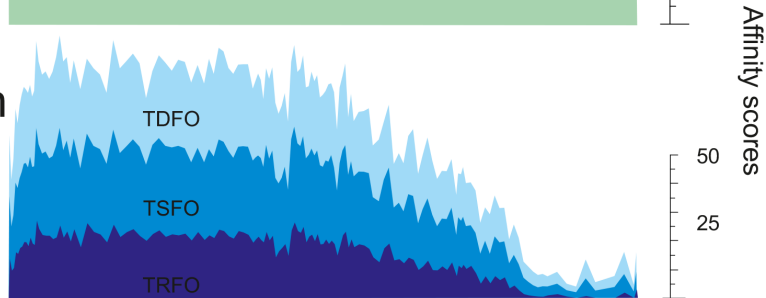

h
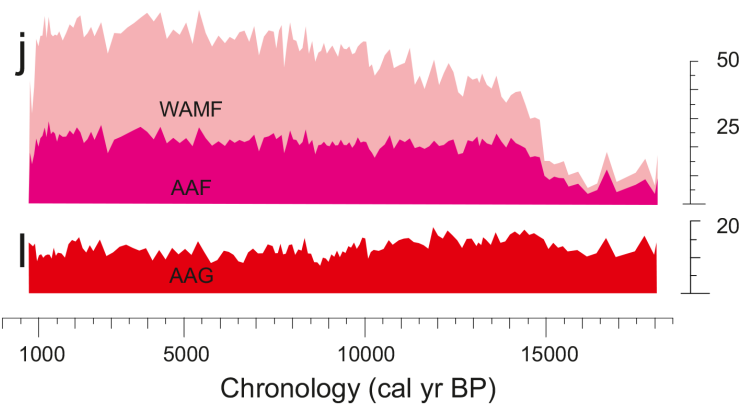

Figure 2. Synthetic pollen diagrams (trees, herbs and undifferentiated; $a-b)$ and affinity scores of each biome (c-l) at Bambili and Rusaka. 
Next, we show each biome score over the last $18 \mathrm{ka}$ at both sites (figure 2c-1). These

258 biome scores are a measure of the likely presence of the biome; both highland (afro-alpine forest 259 (AAF) and warm mixed forest (WAMF)) and lowland (tropical rain forest (TRFO), tropical 260 seasonal forest (TSFO) and tropical dry forest (TDFO)) forest biomes show relatively high 261 affinity scores through the entire period at Bambili (Figure $2 \mathrm{~g}$ and 2i). From $18 \mathrm{ka}$, they 262 increased, through fluctuating, to an optimum that they reach at ca. 14.5 (for the AAF and 263 WAMF) and $10.3 \mathrm{ka}$ (for the TRFO, TSFO and TDFO) during the last deglaciation. The highest 264 affinity scores of all these forest biomes are reached during the phase of developing forests (ca. $26511.5 \mathrm{ka}$ ) according to the pollen diagram (Figure 2a). During the Holocene, in contrast to the 266 relative stability of the montane forest biomes, affinity scores of lowland forests ones decreased 267 from ca. $10.3 \mathrm{ka}$ onward. While they remained relatively stable in spite of a period of slight 268 decline from ca. 4.7 to ca. $1.15 \mathrm{ka}$, the $3.3 \mathrm{ka}$ event (the significant fall of tree pollen percentage) 269 is not recorded in our forest biome reconstructions. On the contrary, all the forest biomes 270 abruptly collapsed at ca. $1.15 \mathrm{ka}$ as shown by the dramatic fall of their cumulative scores, of $50 \%$ 271 within ca. 70 years only. It was only after ca. 0.5 ka that forest biomes recovered and then 272 reached their Holocene affinity-score values (Figure 2g and 2i).

273 The open grass/shrubland biomes (afro-alpine grassland (AAG), steppe (STEP) and 274 desert (DESE)) progressively diminished from ca. $18 \mathrm{ka}$ to ca. $8.2 \mathrm{ka}$, and then gradually 275 increased until the present at Bambili (Figure 2c and 2k). The higher affinity scores of some 276 xerophytic biomes (STEP and DESE) at ca. 3 and ca. $1.15 \mathrm{ka}$ are also consistent with the herb 277 pollen percentage (Figure 2a and 2c). The trends of these biome scores are similar to the trend of 278 herb pollen percentages. On the other hand, the affinity score of savanna (SAVA) was relatively 279 high throughout the whole period (Figure 2e). 
The time interval between ca. 18 and ca. 15 ka had unfavorable conditions for tropical

281 lowland forests (TRFO, TRSO, and TDFO) and montane forests (AAF and WAMF) at Rusaka

282 (Figure $2 \mathrm{~h}$ and $2 \mathrm{j}$ ). The tropical lowland forests started to develop at ca. 14.5ka and then

283 progressively increased until ca. $8.5 \mathrm{ka}$. After the forest expansion was abruptly interrupted

284 between ca. 8.5 and ca. $8 \mathrm{ka}$, the lowland forests remained stable until ca. $1.5 \mathrm{ka}$. On the other

285 hand, the montane forests abruptly increased at ca. $15 \mathrm{ka}$, then followed different trends: in

286 contrast to the AAF which remained stable, the WAMF continuously expanded until ca. 4 ka and

287 then remained relatively stable until ca. $1 \mathrm{ka}$. Among all the phases of forest decrease which

288 punctuated the African Humid Period (ca. 9 ka to ca. 6 ka), only that corresponding to the $8.2 \mathrm{ka}$

289 event is clearly reflected by the sharp decrease of he scores of all the lowland forest biomes. The

290 tropical lowland forests and WAMF recorded a dramatic decline during the last few hundred 291 years.

The affinity scores of xerophytic biomes (AAG, STEP, DESE and SAVA) are higher

293 than those for forest biomes during the period between ca. $18 \mathrm{ka}$ and ca. $15 \mathrm{ka}$, which is

294 consistent with the pollen percentages at Rusaka (Figure 2b, 2d, $2 \mathrm{f}$ and 21). The affinity scores of

295 the xerophytic biomes did not largely change through the entire period, but there is an opposite

296 trend between highlands and lowlands: the AAG progressively decreases and the other biomes

297 progressively increase from the glacial period to the present. The Holocene evolution of SAVA,

298 STEP and DESE was punctuated by phases of slight reduction at ca. 12, 10.5, 3.7-3.2, and 2.1

299 ka.

300 Figure 3 shows the first and second dominant biomes for representing the main biome

301 changes at Bambili and Rusaka sites. We chose a biome with the highest affinity score as the

302 first dominant biome and a biome with the next highest score as the second dominant one. The 
303 higher ratios of the second dominant biome affinity score to the first dominant biome affinity

304 score express the potential co-existence of these biomes. The first dominant biome over the

305 Holocene is the warm-mixed forest (WAMF), which is in particular the sole dominant biome

306 except ca. $1 \mathrm{ka}$ and ca. $9 \mathrm{ka}$, and it has relatively high affinity scores at both sites, but there are

307 different biome distributions and have lower affinity scores (than the Holocene) between the two

308 sites prior to the Holocene. The WAMF was already the first dominant biome from ca. $15 \mathrm{ka}$,

309 and before the establishment of the forest, savanna (SAVA) was the first dominant biome at

310 Bambili. On the other hand, the WAMF was first dominant biome from ca. $13 \mathrm{ka}$, and before the

311 forest establishment, afro-alpine forest (AAF, ca. $15 \mathrm{ka}$ to ca. $13 \mathrm{ka}$ ) and afro-alpine grass (AAG,

312 ca. $18 \mathrm{ka}$ to ca. $15 \mathrm{ka}$ ) was the first dominant biome at Rusaka.

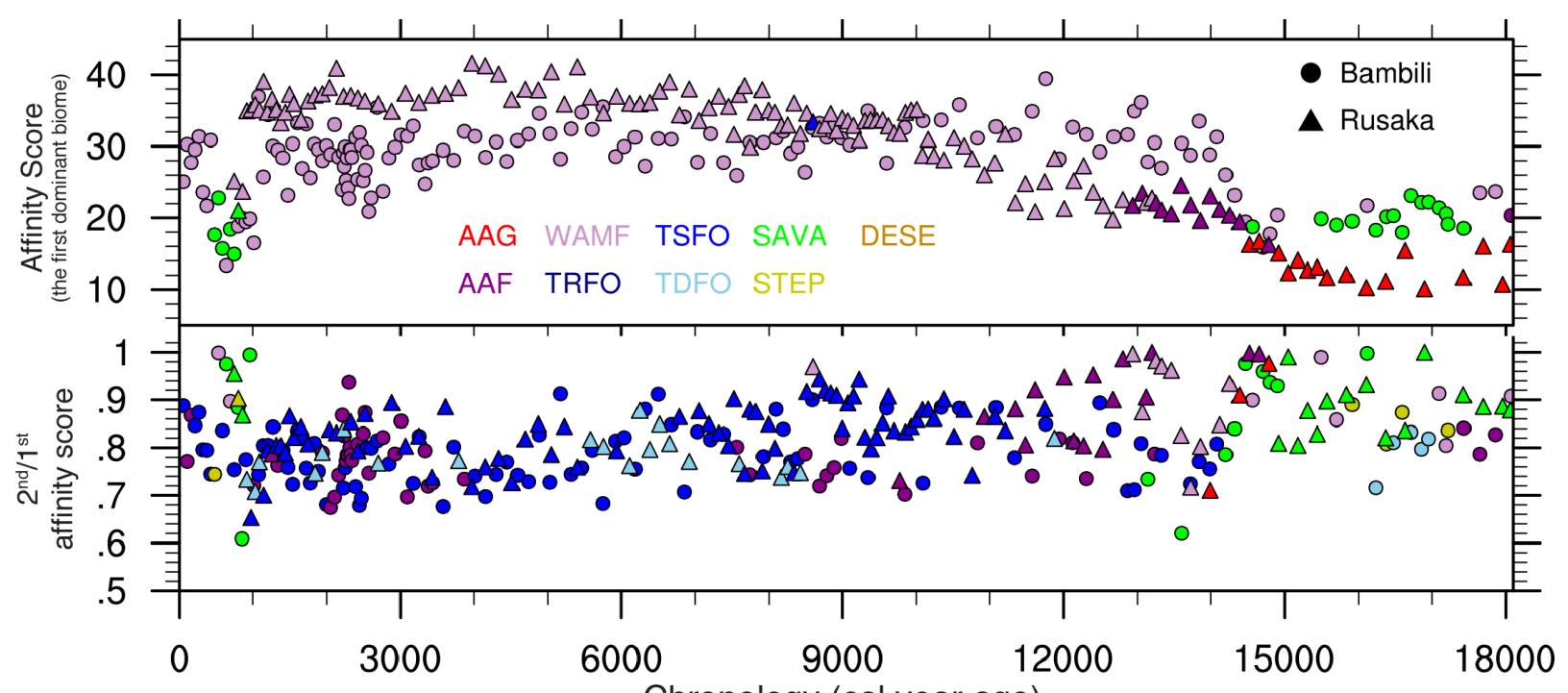

313

314

315

316

317

318

319

320

Figure 3. The first and second dominant biomes and their affinity scores at Rusaka and Bambili. The first dominant biome affinity score is shown with the absolute value (top). The affinity scores of the second dominant biomes are shown with the ratio of the second biome affinity score to the first biome one (bottom).

\subsection{Effects of atmospheric $\mathrm{CO}_{2}$ concentration to vegetation}

Unlike the sensitivity experiment in Jolly and Haxeltine (1997), our sensitivity experiment does not show a shift of the warm mixed forest (WAMF) to the target xeric biomes 
321 (afro-alpine forest (AAF) at Bambili and afro-alpine grassland (AAG) at Rusaka) by the

322 decreases in atmospheric $\mathrm{CO}_{2}$ alone (not shown). But, under the lower $\mathrm{CO}_{2}$ concentrations, the

323 simulated net primary production (NPP) largely decreases for most of the forest-related plant

324 functional types (PFTs) and slightly decreases for shrub- and grass-related PFTs (Fig. 4). The

325 sensitivity analysis thus shows that the xerophytic biomes have relatively higher NPP and thus

326 more easily expand than forest biomes under lower atmospheric $\mathrm{CO}_{2}$ concentrations. To a greater

327 or lesser extent, these responses are consistent among the BIOME models (i.e., BIOME3,

328 BIOME4, and BIOME5-beta).
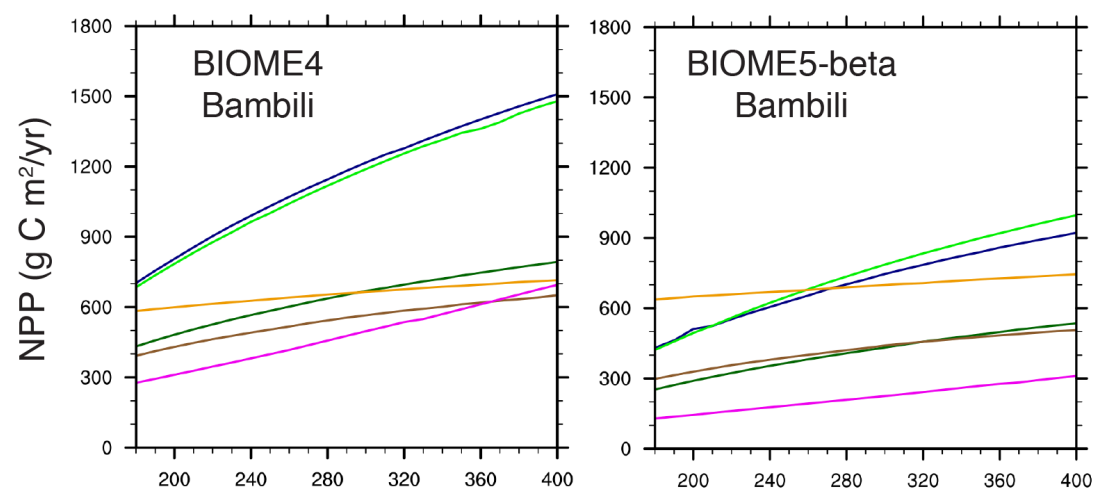

Tropical broadleaf evergreen trees

Tropical broadleaf raingreen trees

Temperate broadleaf evergreen trees
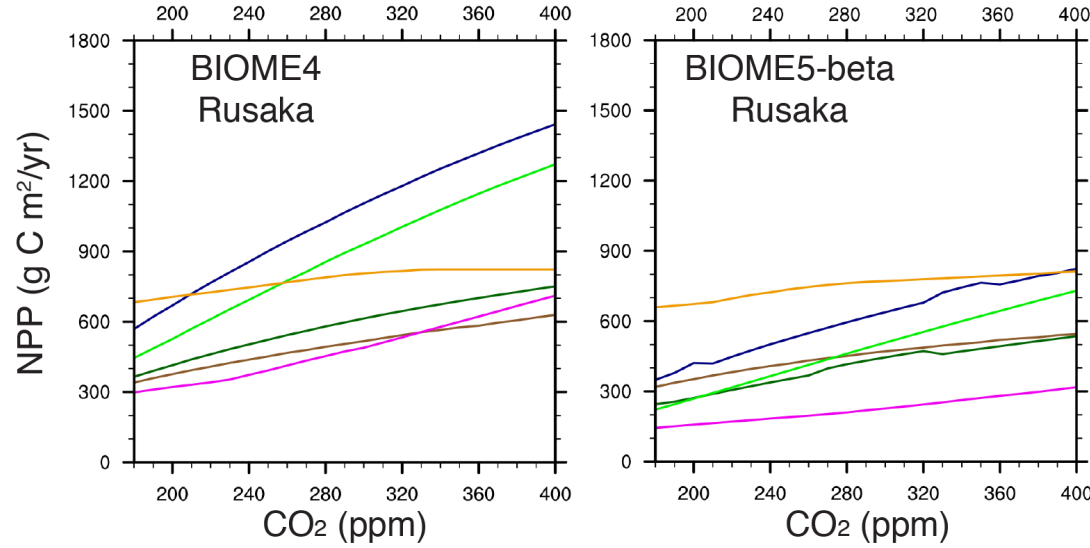

Temperate needleleaf evergreen trees

Tropical/temperate shrub

Tropical grass

329

330

331

332

333

334

335

Figure 4. Change in net primary production (NPP) in the sensitivity experiment. In running the vegetation models (i.e., BIOME4 and BIOME5-beta), we use the altitude-adjusted air pressure $\left(7.7 \times 10^{4} \mathrm{~Pa}\right.$ at Bambili, $7.9 \times 10^{4} \mathrm{~Pa}$ at Rusaka). The climate input comes from CRU CL 2.0 data at each site.

To illustrate the possible climate spaces for target vegetation (i.e., AAF at Bambili and AAG at Rusaka) under the different atmospheric $\mathrm{CO}_{2}$ concentration, we estimated mean annual 
temperature (MAT, ${ }^{\circ} \mathrm{C}$ ) and mean annual precipitation (MAP, mm/year) using the IMIFM

337 approach with both BIOME5-beta and BIOME4 vegetation models (Fig. 5). This target

338 vegetation is the observed first dominant biome, which has the highest affinity score, at the early

339 in the last deglaciation (i.e., $18 \mathrm{ka}$ ) (the rightest part in Fig. 3). According to observed climate

340 data, CRU CL 2.0 (New et al., 2002), although MAT is similar at both sites, MAP at Rusaka is

341 less than half at Bambili (Figure 5), and thus Rusaka is likely to experience drier conditions than

342 Bambili for vegetation at both the present and past.

343

344

345

346

347

348

349

350

351

352

353

354

355

356

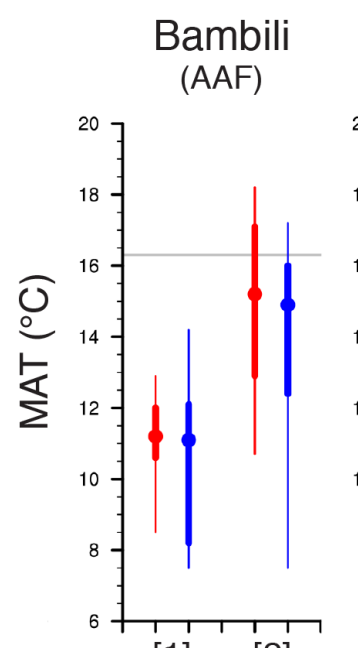

[1] [2]
Rusaka

(AAG)

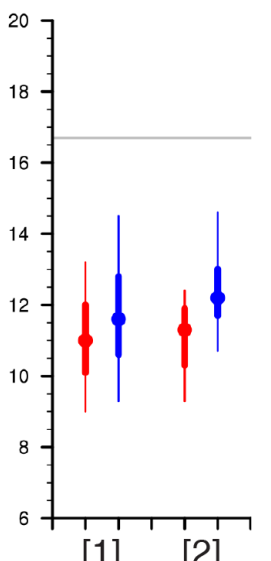

BIOME5-beta

BIOME4

[1] 194. ppm

[2] 331. ppm

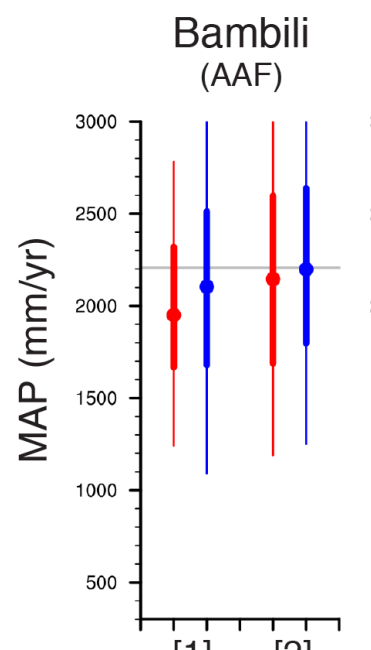

[1] [2]

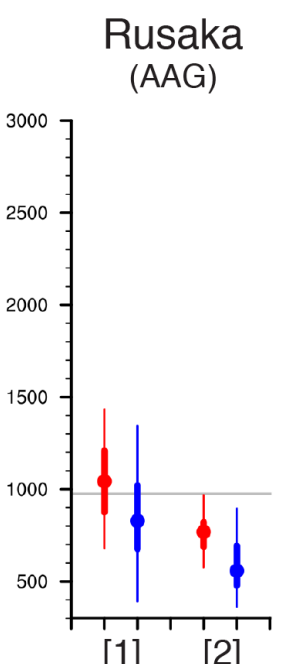

[1] [2]

Figure 5. Potential climate (mean annual temperature (MAT) and mean annual precipitation (MAP)) spaces for target vegetation (i.e., afro-alpine forest (AAF) at Bambili and afro-alpne grass (AAG) at Rusaka) at ca. $18 \mathrm{ka}$ (18,071 years ago at Bambili and 18,061 years ago at Rusaka) using the IMIFM approach with two vegetation models through two experiments: [1] paleo $\mathrm{CO}_{2}$ concentration (194. ppm) and [2] modern $\mathrm{CO}_{2}$ concentration (331. ppm). Dots indicate median values, bold vertical lines indicate interquartile intervals $\left(25^{\text {th }}\right.$ to $75^{\text {th }}$ percentile $)$, and thin vertical lines indicate $90 \%$ interval $\left(5^{\text {th }}\right.$ to $95^{\text {th }}$ percentile) for probability distribution of each climatic variable from BIOME5-beta (blue) and BIOME4 (red) respectively. The gray lines indicate observed modern values from the CRU CL2.0 (New et al., 2002) data at each site.

The difference of atmospheric $\mathrm{CO}_{2}$ concentration (i.e., $331 \mathrm{ppm}$ at $0 \mathrm{ka}$ vs. $194 \mathrm{ppm}$ at ca. $18 \mathrm{ka}$ ) also influences plant productivity and climate spaces for the target vegetation (i.e. $\mathrm{AAF}$ at Bambili and AAG at Rusaka) (Figure 5 [1] and [2]). The change in atmospheric $\mathrm{CO}_{2}$ level (i.e., from $331 \mathrm{ppm}$ to $194 \mathrm{ppm}$ ) decreases the simulated GPP, AR, and NPP by $30-45 \%$ at 
357 Bambili with both vegetation models, but changes in these variables are different between the

358 vegetation models at Rusaka; BIOME4 shows a greater response than the BIOME5-beta related

359 to the different carbon-use efficiency simulation between models. At Rusaka, BIOME5-beta

360 slightly increases in AR and decreases in both GPP and NPP, and there is different responses

361 between grass-type biomes and woody-type biomes in the single model. Compared to the

362 modern $\mathrm{CO}_{2}$ experiment (Figure 5 [2]), the paleo $\mathrm{CO}_{2}$ experiment (Figure 5 [1]) with both

363 models shows that the MAT drops by around $4{ }^{\circ} \mathrm{C}$ and MAP decreases about $150 \mathrm{~mm} / \mathrm{year}$ at

364 Bambili, and that MAT drops about $0.5-1{ }^{\circ} \mathrm{C}$ and MAP increases about $200-300 \mathrm{~mm} / \mathrm{year}$ at

365 Rusaka. The response of the forest-type biome (i.e. AAF at Bambili) to the change in

366 atmospheric $\mathrm{CO}_{2}$ concentration is much larger than one of the grass-type biome (i.e. AAG at

367 Rusaka).

368 5. Discussion

\section{$369 \quad 5.1$ Vegetation changes}

370 Inspection of the formula for calculating affinity scores in the biomization procedure,

371 shows that the scores for each biome do not simply reflect the sum of pollen percentages that

372 constitutes each biome. If the percentage of the pollen sum that constitutes each biome is fixed,

373 greater diversity among taxa for a given biome will automatically yield a higher affinity score

374 (Prentice and Webb, 1998). Therefore, the trends of pollen abundance and affinity scores will not

375 necessarily be consistent even if we use the exact same pollen data (Figure 2). However, the

376 general trend of forest expansion, forest establishment, and forest degradation described using

377 both pollen percentages and biome scores at Bambili and Rusaka is mutually consistent here. 
We also calculated other biome score ratios: AAG/AAF for implying the vertical

379 migration of the tree line in mountains (Figure 6a), and TRFO/STEP (i.e., the most humid biome

380 versus the one of the most arid biomes) for implying the lowland changes in biomes mainly

381 linked to moisture changes (Figure 6b). AAG/AAF displays a parallel trend at both sites with

382 high values at levels dated from 18 to $14.5 \mathrm{ka}$. AAG/AAG values abruptly fall at 14.5 (Ruzaka)

383 or $13.7 \mathrm{ka}$ (Bambili) then remain stable during the Holocene until the last millennium where a

384 sharp increase is observed. Conversely TRFO/STEP values increase from $18 \mathrm{ka}$ to 14.7

385 (Rusaka)-14ka (Bambili) with values substantially higher at Bambili compared to Rusaka. In this

386 latter site, they remain stable during the Holocene, whereas the dramatically increase during the

387 mid-and late Holocene at Bambili.

388

389

390

391

392

393

394

395

396

397
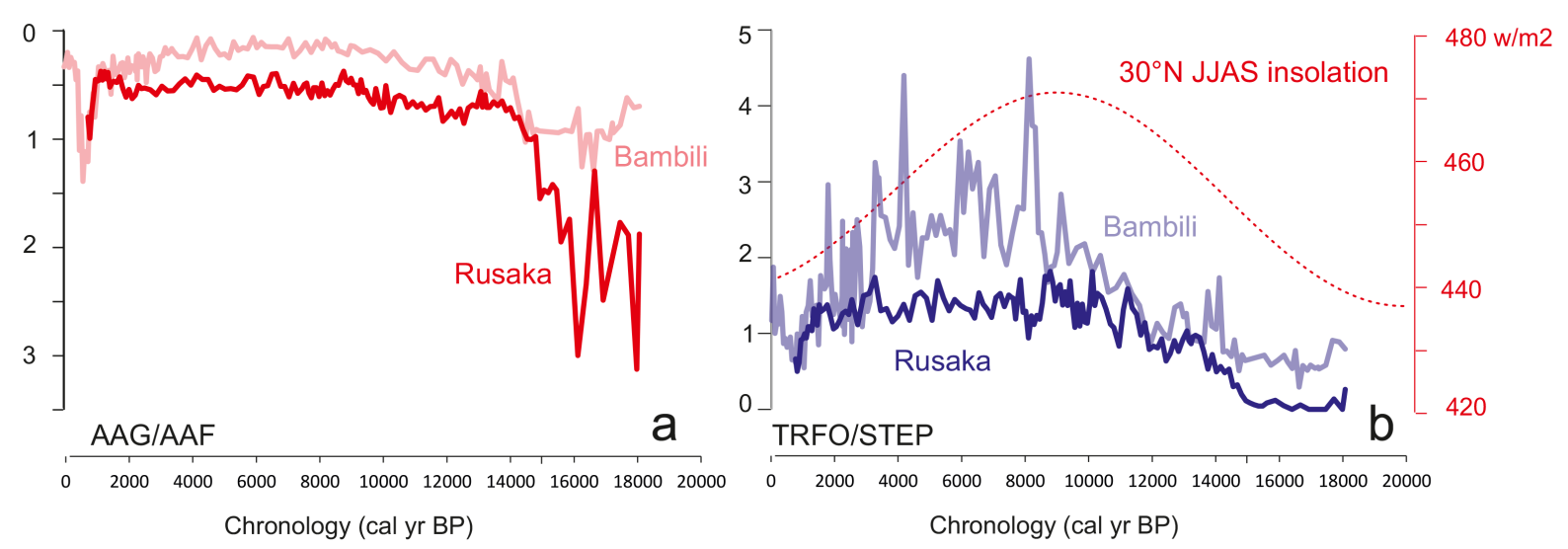

Figure 6. AAG/AAF ratio illustrating the descent of the tree line at Rusaka and Bambili (a) and TRFO/STEP ratio illustrating the expansion of the lowland forests in relation with increased humidity (b). $30^{\circ} \mathrm{N} \mathrm{JJAS}$ insolation from Berger and Loutre, 1991.

One of the remarkable results of our analysis is the characterization of the period prior to the Holocene forest establishment. The first dominant biome over the Holocene is the warm mixed forest (WAMF) at both Bambili and Rusaka, but the biome distributions were different between the two sites prior to the Holocene (i.e., WAMF and savanna (SAVA) at Bambili and AAF and afro-alpine grass (AAG) at Rusaka) (Figure 3). While the extreme reduction of all kinds of forests is coeval with both the expansion of the lowland grasslands and shrublands and 
398 the downward shift of the Afroalpine grasslands (Figure 6a) during glacial times at Rusaka, such

399 a shrinkage was not observed at Bambili where all forest biomes were present at that time - even

400 with noticeable reduction of their population size - and where the downward shift of the

401 Afroapline belt was much less pronounced (Figure 6a)

Our result proposes that the eastern and western sectors of the Guineo-Congolian forest

403 domain had the following distinct environmental conditions: northwest Cameroon benefited from

404 conditions favorable to forest persistence at both low and high elevation in spite of dryness

405 related to Heinrich event 1 (H1, ca. $17 \mathrm{ka}$ ) (Stager et al., 2002). The forest domain was probably

406 not as fragmented as previously thought (Maley, 1996). Lower atmospheric $\mathrm{CO}_{2}$ concentration

407 and regional dryness allowed for xerophytic biomes to expand in the lowlands. For some

408 vegetation, the impact of lower $\mathrm{CO}_{2}$ concentration is equivalent to that of increased dryness

409 (Loehle, 2007). By comparison, the environment was too dry in the Burundi highlands for the

410 persistence of any kind of forests.

411 Atmospheric $\mathrm{CO}_{2}$ concentrations over the Holocene were still lower than modern, but the

412 impact on the vegetation is generally considered to be negligible for practical purposes. Here, the

413 expansion of xerophytic biomes mainly results from increased dryness. As shown by the

414 TRFO/STEP ratio (Figure 6b), the expansion of moist forest biomes in the lowlands at both sites

415 closely matches the insolation trend (Braconnot et al., 2007a, 2007b) and related fluctuations in

416 monsoon rainfall since ca. 15 ka (e.g., deMenocal et al., 2000; Weldeab et al., 2005; Gasse et al.,

417 2000, 2008; Lézine et al., 2011; Tierney et al., 2008; Tierney and deMenocal, 2013). Unlike

418 Rusaka where the driest biomes continued into the Holocene, Bambili recorded a drastic decline

419 of STEP and DESE, which corresponded to the onset of the "African Humid Period" i.e the

420 widespread expansion of tropical forests and woodlands in northern Africa (deMenocal et al., 
421 2000; Lézine et al., 2011; Hély and Lézine, 2014). Moist conditions led to the progressive forest

422 expansion in the lowlands as shown by the increase of their biome scores (Figure 2) during the

423 period 15-8.5ka (the Younger Dryas (YD) interval excluded) contrary to WAMF, which abruptly

424 developed within centuries. Then the WAMF dominated in the surroundings of the lake at both 425 sites all along the Holocene (Figure 3).

The YD climate reversal is associated with an intense drought in the African tropics

427 (Gasse et al., 2008), which was responsible for forest disruption (see the fall in tree pollen

428 percentages, Figure 2) but that only slightly affected the biome distribution (Figure 2). This is

429 confirmed by the only small decrease of the TRFO/STEP ratio (Figure 6b). In contrast, the $8.2 \mathrm{ka}$

430 dry event (Alley, 1997) is particularly clear at Rusaka where the lowland forest biomes suddenly

431 dropped (Figure 2). Moreover, the intrusion of TDFO as the second dominant biome after this

432 event at this site (Figure 3) testifies for drier conditions in relation with a longer dry season as

433 already observed in tropical Africa (e.g., Vincens et al., 2010). At Bambili however, diversity

434 changes (an increase of light-demanding trees) induced by repeated dry seasons from ca. $8.2 \mathrm{ka}$

435 onward (Lézine et al., 2013a) did not significantly affect the representativeness of the forest

436 biomes, and the WAMF remained dominant up to the last millennium. An increase in drought at

437 this site during the $8.2 \mathrm{ka}$ event is only signaled by the higher scores of DESE and STEP.

The two-step disruption of the forest at the end of the African Humid Period at ca. $3.3 \mathrm{ka}$

439 and then during the last millennium (Figure 2, tree pollen percentages) clearly corresponded to

440 dry periods as shown by the increase of open grassland/shrubland biomes. The last millennium is

441 by far the most disturbed period of all the late Holocene. The sudden decline of all the forest

442 biomes at ca. 1.2 ka correlates the dry event already recorded in Equatorial Central (Brncic et al., 443 2009) and East Africa (Verschuren et al., 2000) at the time of the 'Medieval Warm Period'. One 
444 cannot however exclude the role of human populations who widely expanded at that time

445 (Lézine et al., 2013b) in the forest degradation.

\section{$446 \quad 5.2$ Effects of atmospheric $\mathrm{CO}_{2}$ concentration on vegetation}

447 Our study shows that changes in atmospheric $\mathrm{CO}_{2}$ concentration impact on plant

448 productivity and vegetation distribution and thus possibly influence climate spaces for the

449 vegetation in equatorial mountains of African. These results are consistent with previous studies.

450 However, although Jolly and Haxeltine (1997) already proposed that low atmospheric $\mathrm{CO}_{2}$ alone

451 could result in the observed replacement of tropical montane forest by scrub vegetation, this

452 dramatic change apparently depends on the local climate and vegetation model used. As a result,

453 whether the vegetation prior to the Holocene is due to lower atmospheric $\mathrm{CO}_{2}$ concentration

454 relative to present, changes in the climate, or their combination is an unresolved question (Wu et

455 al., 2007b). Sensitivity experiments can be used to assess the impacts of a change in atmospheric

$456 \mathrm{CO}_{2}$ concentration on vegetation, but it is difficult to consider the impacts of climate changes on

457 vegetation at the same time because similar vegetation can exist under a wide climate space.

458 Thus, the inverse-vegetation modeling approach (e.g., Wu et al., 2007a, b; Izumi and Bartlein, in

459 revision) can be one option for investigating impacts of changes in the atmospheric $\mathrm{CO}_{2}$

460 concentration and climate on vegetation.

461 The changes in atmospheric $\mathrm{CO}_{2}$ concentration potentially result in large impacts on

462 vegetation and climate reconstruction based on the vegetation in our sites. Our MAT estimation

463 at ca. $18 \mathrm{ka}$ shows the similar values at Bambili and Rusaka because the target biomes are similar

464 afromontane biomes at the two sites. When we take into account modern MAT at each site, we

465 can therefore suggest similar temperature decreases at ca. 18ka in equatorial mountains of Africa. 
466 According to our sensitivity experiment and IMIFM approach for climate reconstruction, the

467 vegetation changes from xerophytic biomes (afro-alpine forest (AAF) and afro-alpine grass

468 (AAG)) to warm mixed forest (WAMF) prior to the Holocene result from both the increase in

469 atmospheric $\mathrm{CO}_{2}$ concentration and surface air temperature.

470 Our mean annual precipitation (MAP) estimation does not vary accompanying changes in

471 atmospheric $\mathrm{CO}_{2}$ concentration in particular at Bambili, partly because of the impact of lower

$472 \mathrm{CO}_{2}$ concentration on water-use efficiency (WUE; the ratio of rate of photosynthesis to the rate

473 of transpiration) in vegetation. If climate did not vary between the present and the past (at ca. 18

$474 \mathrm{ka}$ ), the paleo vegetation in particular xerophytic biomes would still appear drier than present,

475 simply because of decreased WUE. WUE is sensitive to changes in atmospheric $\mathrm{CO}_{2}$ through

476 effects on stomatal conductance, and consequently a decrease in WUE results from low $\mathrm{CO}_{2}$

477 concentration (Lochle, 2007; Prentice and Harrison, 2009). Moreover, in spite of the similar

478 afromontane biomes at the two site, the MAP reconstructions are opposite between the two sites

479 because of the different WUE responses between forest-type and grass-type biomes to the lower

$480 \mathrm{CO}_{2}$ concentration. This MAP increase at Rusaka also implies that climate reconstruction at ca.

$48118 \mathrm{ka}$ would appear too dry if the decrease in atmospheric $\mathrm{CO}_{2}$ concentrations was not

482 considered. There are different responses in plant productivity between AAG (at Rusaka) and

483 AAF (at Bambili) to a change in atmospheric $\mathrm{CO}_{2}$ concentration (e.g., AAF has larger

484 responses), and this has a large impact on climate reconstruction but one that depends on the

485 vegetation models and vegetation types. The different types of biomes at Bambili and Rusaka

486 possibly result from both the regionally different dryness and the lower atmospheric $\mathrm{CO}_{2}$ 487 concentration. 
Inverse-vegetation modeling approaches also have many challenges. One of the most

489 significant issues is that the results depend on the vegetation model used (Guiot et al., 2009). In

490 this study, we used the two equilibrium vegetation models, and there were some opposing

491 responses between the models, and thus we need to further evaluate the models if we wish to

492 produce robust results. Moreover, the inverse-vegetation modeling approach in Wu et al. (2007a,

493 b) assumed that last glacial period was drier than the present and thus their potentially prescribed

494 precipitation range was lopsided (i.e., $-90 \%$ to $50 \%$ of modern values). But, if we do not have

495 any evidence for the potential climate space (e.g. from lake-status data), we should search over a

496 wider climate space (e.g., $-90 \%$ to $90 \%$ of modern values) for the target vegetation.

\section{6. Conclusion}

Comparing two mountain sites located in different environments of equatorial Africa

499 sheds some new light on the response of plant formation (i.e. biomes) to climate changes:

500 (i) two major events characterize the changes biome distribution over the last $18 \mathrm{ka}$. Taking into

501 account uncertainties of the age models, their timing is remarkably similar east and west of the

502 Congo basin: the post-glacial development of all the forest biomes ca. $14.5 \mathrm{ka}$ and their collapse

503 during the last millennium; (ii) contrary to the lowlands where forests biomes expanded

504 progressively, the montane forest development was abrupt, occurring within centuries. Mountain

505 biomes then remained remarkably stable throughout the Holocene contrasting with the repeated

506 fluctuations in the arboreal forest cover revealed by the tree pollen percentages. In particular, the

507 forest decline during the Younger Dryas and at the end of the Holocene Humid Period at ca. 3.3

508 ka is not or only slightly reflected in the forest biome scores; (iii) the amplitude of the collapse of

509 all the forest biome during the last millennium is remarkable and points to the major impact of

510 the Medieval warm period in the deep tropics. 
511 Our sensitivity experiment and inverse-vegetation modeling approach show that

512 atmopsheric $\mathrm{CO}_{2}$ concentration unequally impact on vegetation due to different local

513 environments such as climates at each site. This study also suggests that the biome changes prior

514 to the Holocene resulted from both changes in the atmopsheric $\mathrm{CO}_{2}$ concentration and climate;

515 the development and establishment of warm mixed forest from the xerophytic vegetation results

516 from increases in atmopsheric $\mathrm{CO}_{2}$ concentration and near-surface air temperature. The

517 difference of local dryness also influences the biome distribution between the two sites, more

518 forest-type biome at Bambili and more grass/shrub-type biome at Rusaka. Finally, our climate

519 reconstruction proposes that the post-glacial climate in equatorial Africa may have been more 520 mesic than previous studies suggest.

\section{Acknowledgements}

522 This research was funded by the National Research Funding Agency in France (ANR-09-PEXT-

$523001 \mathrm{C} 3 \mathrm{~A})$ and the Belgian Federal Science Policy Office (BR/132/A1/AFRIFORD). Rusaka

524 pollen data were extracted from the African Pollen Database (http://fpd.sedoo.fr/fpd/) and

525 Bambili pollen data are available from the AML. We thank H. Chevillotte and S. Janicot for their

526 contribution. We are also grateful Patrick Bartlein and two anonymous reviewers for their

527 insightful comments on the manuscript. KI is supported by Labex L-IPSL and AML is supported 528 by CNRS.

\section{References}

530 Alley, R. B., 1997. Holocene climatic instability; a prominent, widespread event 8,200 yr ago. 531 Geology 25, 483-486. 
532 Amaral, P. G. C., Vincens, A., Guiot, J., Buchet, G., Deschamps, P., Doumnang, J.-

533 C., Sylvestre, F., 2013. Palynological evidence for gradual vegetation and climate changes

534 during the African Humid Period termination at $13^{\circ} \mathrm{N}$ from a Mega-Lake Chad 535 sedimentary sequence. Climate of the Past 9, 223-241.

536 Anadón, J. D., Sala, O. E., Maestre, F. T., 2014. Climate change will increase savannas at the 537 expense of forests and treeless vegetation in tropical and subtropical Americas. Journal of $538 \quad$ Ecology 102, 1363-1373.

539 Bazin, L., 2013. Carbon dioxide composite data on AICC2012 chronology. $540 \quad$ Doi:10.1594/PANGAEA.824893

541 Berger, A., Loutre, M. F., 1991. Insolation values for the climate of the last 10 million years. 542 Quaternary Science Reviews 10, 297-317.

543 Bonnefille, R., Potts, R., Chalié, F., Jolly, D., Peyron, O., 2004. High-resolution vegetation and 544 climate change associated with Pliocene Australopithecus afarensis. Proceedings of the 545 National Academy of Sciences of the United States of America 101, 33, 12125-12129.

546 Bonnefille, R., Riollet, G., Buchet, G., Icole, M., Lafont, R., Arnold, M., Jolly, D., 1995.

547 Glacial/Interglacial record from Intertropical Africa, high resolution pollen and carbon data 548 at Rusaka, Burundi. Quaternary Science Reviews 14, 917-936.

549 Braconnot, P., Otto-Bliesner, B., Harrison, S., Joussaume, S., Peterchmitt, J.-Y., Abe-Ouchi, A., 550 Crucifix, M., Driesschaert, E., Fichefet, T., Hewitt, C. D., Kageyama, M., Kitoh, A., Laine, 551 A., Loutre, M.-F., Marti, O., Merkel, U., Ramstein, G., Valdes, P., Weber, S. L., Yu, Y., 552 Zhao, Y., 2007a. Results of PMIP2 coupled simulations of the mid-Holocene and Last 553 Glacial maximum e part 1: experiments and large-scale features. Climate of the Past 3, $554 \quad 261-277$. 
555 Braconnot, P., Otto-Bliesner, B., Harrison, S., Joussaume, S., Peterchmitt, J.-Y., Abe-Ouchi, A., 556 Crucifix, M., Driesschaert, E., Fichefet, T., Hewitt, C. D., Kageyama, M., Kitoh, A., Laine, 557 A., Loutre, M.-F., Marti, O., Merkel, U., Ramstein, G., Valdes, P., Weber, S. L., Yu, Y., 558 Zhao, Y., 2007b. Results of PMIP2 coupled simulations of the mid-Holocene and Last 559 Glacial maximum - part 2: feedbacks with emphasis on the location of the ITCZ and mid560 and high latitudes heat budget. Climate of the Past 3, 279-296.

561 Brncic, T.M., Willis, K.J., Harris, D.J., Telfer, M.W., Bailey, R.M., 2009. Fire and climate 562 change impacts on lowland forest composition in northern Congo during the last 2580 563 years from palaeoecological analyses of a seasonally flooded swamp. The Holocene 19,1, $564 \quad 79-89$.

565 Brooks, A., Farquhar, G. D., 1985. Effect of temperature on the CO2/O2 specificity of ribulose566 1,5-bisphosphate carboxylase/oxygenase and the rate of respiration in the light. Planta 165, $567 \quad 397-406$.

568 Cowling, S. A., Sykes, M. T., 1999. Physiological significance of low atmospheric $\mathrm{CO}_{2}$ for 569 plant-climate interactions, Quaternary Research 52, 237-242.

570 de Menocal, P., Ortiz, J., Guilderson, T., Adkins, J., Sarnthein, M., Baker, L., Yarusinsky, M. 5712000 . Abrupt onset and termination of the African Humid Period: rapid climate responses 572 to gradual insolation forcing, Quaternary Science Reviews 19, 347-361.

573 Desjardins, T., Turcq, B., Nguetnkam, J.-P., Achoundong, G., Mandeng-Yogo, M., Cetin, F., 574 Lézine, A.-M., 2013. $\mathrm{d}^{13} \mathrm{C}$ variations of soil organic matter as an indicator of vegetation 575 change during the Holocene in central Cameroon. C.R. Geosciences 345, 266-271. 
576 Dupont, L. M., Jahns, S., Marret, F., Shi, N., 2000. Vegetation change in equatorial West Africa:

577 time-slices for the last 150 ka. Palaeogeography, Palaeoclimatology, Palaeoecology 155, $578 \quad 95-122$.

579 Ehleringer, J. R, Cerling, T. E., Helliker, B. R., 1997. C4 photosynthesis, atmospheric $\mathrm{CO}_{2}$ and $580 \quad$ climate. Oecologia 112, 285-299.

581 Elenga H., Peyron O., Bonnefille R., Prentice I.C., Jolly D., Cheddadi R., Guiot J., Andrieu V., 582 Bottema S., Buchet G., de Beaulieu J.-L., Hamilton A.C., Maley J., Marchant R., Perez583 Obiol R., Reille M., Riollet G., Scott L., Straka H., Taylor D., Van Campo E., Vincens A., 584 Laarif F., Jonson H., 2000. Pollen-based biome reconstruction for southern Europe and 585

586 Friend, A. D., Woodward, F. I., 1990. Evolutionary and ecophysiological responses of mountain 587 plants to the growing season environment. Advances in Ecological Research 20, 59-124.

588 Food and Agricultural Organization of the United Nations (FAO), 1995. Digital Soil Map of the 589 World and Derived Soil Properties (Version 3.5), FAO, Rome, Italy.

590 Gasse, F., 2000. Hydrological changes in the African tropics since the Last Glacial Maximum, 591 Quaternary Science Reviews 19, 189-211.

592 Gasse, F., Chalié, F., Vincens, A., Williams, M. A. J., Williamson, D., 2008. Climatic patterns in 593 equatorial and southern Africa from 30,000 to 10,000 years ago reconstructed from 594 terrestrial and near-shore proxy data. Quaternary Science Reviews 27, 2316-2340.

595 Guiot, J., Torre, F., Jolly, D., Peyron, O., Boreux, J. J., Cheddadi, R., 2000. Inverse vegetation 596 modeling by Monte Carlo sampling to reconstruct palaeoclimates under changed 597 precipitation seasonality and $\mathrm{CO} 2$ conditions: application to glacial climate in 598 Mediterranean region. Ecological Modelling 127, 2-3, 119-140. 
599 Guiot, J., Wu, H. B., Garreta, V., Hatte, C., Magny, M., 2009 A few prospective ideas on climate 600 reconstruction: from a statistical single proxy approach towards a multi-proxy and 601 dynamical approach. Climate of the Past 5, 4, 571-583.

602 Hély, C., Lézine, A.-M. and contributors, 2014. Holocene changes in African vegetation: 603 tradeoff between climate and water availability. Climate of the Past 10, 681-686.

604 Huang, Y. S., Street-Perrott, F. A., Perrott, R. A., Metzger, P., Eglinton, G., 1999. Glacial605 interglacial environmental changes inferred from molecular and compound-specific $\delta^{13} \mathrm{C}$ 606 analyses of sediments from Sacred Lake My. Kenya. Geochimica et Cosmochimica Acta $607 \quad 63,1383-1404$.

608 Izumi, K., 2014. Application of paleoenvironmental data for testing climate models and 609 understanding past and future climate variations. $\mathrm{PhD}$ Thesis, Universite of Oregon, 610 Eugene, USA.

611 Izumi, K., Bartlein, P. J., in revision. North American paleoclimate reconstructions for the last 612 glacial maximum using an inverse-modeling through iterative-forward-modeling (IMIFM) 613 approach applied to pollen data. Geophysical Research Letters.

614 Jolly, D., Harrison, S. P., Damnati, B., Bonnefille, R., 1998b. Simulated climate and biomes of 615 Africa during the late Quaternary: comparison with pollen and lake status data. Quaternary $616 \quad$ Sciences Reviews 17, 629-657.

617 Jolly, D., Haxeltine, A., 1997. Effect of low glacial atmospheric $\mathrm{CO}_{2}$ on tropical African 618 montane vegetation. Science 276, 786-788. doi:10.1126/science.276.5313.786

619 Jolly, D., Prentice, I. C., Bonnefille, R., Ballouche, A., Bengo, M., Brenac, P., Buchet, G., 620 Burney, D., Cazet, J. P., Cheddadi, R., Edorh, T., Elenga, H., Elmoutaki, S., Guiot, J., 621 Laarif, F., Lamb, H., Lézine, A.-M., Maley, J., Mbenza, M., Peyron, O., Reille, M., 
Reynaud-Farrera, I., Riollet, G., Ritchie, J. C., Roche, E., Scott, L., Ssemmanda, I., Straka, H., Umer, M., Van Campo, E., Vilimumbalo, S., Vincens, A., Waller, M., 1998a. Biome reconstructions from pollen and plant macrofossil data for Africa and the Arabian peninsula at 0 and 6000 yrs. Journal of Biogeography 25, 1007-1027.

Kaplan, J. O., Bigelow, N. H., Prentice, I. C,. Harrison, S. P., Bartlein, P. J., Christensen, T. R., Cramer, W., Matveyeva, N. V., McGuire, A. D., Murray, D. F., Razzhivin, V. Y., Smith, B., Walker, D. A., Anderson, P. M., Andreev, A. A., Brubaker, L. B., Edwards, M. E.,

632 Lebamba, J., Vincens, A., Maley, J., 2012. Pollen, vegetation and climate at Lake Barombi Mbo

633 (Cameroon) during the last ca. $33000 \mathrm{cal}$ yr BP: a numerical approach. Climate of the the $634 \quad$ Past 8, 59-78.

635 Letouzey, R., 1968. Etude phytogéographique du Cameroun. P. Lechevalier ed., Paris 511p.

636 Letouzey, R., 1985. Notice de la carte phytogéographique du Cameroun au 1:500 000. Institut 637 de la Carte Internationale de la Végétation, Toulouse, France.

638 Lézine, A.-M., 2007. Postglacial Pollen Records of Africa. In Encyclopaedia of Quaternary 639 Sciences, Scott A Elias ed., Elsevier. 4, 2682-2698.

640 Lézine, A.-M., Assi-Kaudjhis, C., Roche, E., Vincens, A., Achoundong, G., 2013a. Towards an 641 understanding of West African montane forest response to climate change. Journal of $642 \quad$ Biogeography 40, 1, 183-196. 
643 Lézine, A.-M., Hély, C., Grenier, C., Braconnot, P., Krinner, G., 2011. Sahara and Sahel 644 vulnerability to climate changes, lessons from paleohydrological data. Quaternary 645 Science Reviews 30, 21-22, 3001-3012.

646 Lézine, A.-M., Holl, A., Assi-Kaudjhis, C., Février, L., Lebamba, J., Vincens, A., Sultan, E., 647 2013b Central African forests, human populations and climate during the Holocene. C.R. $648 \quad$ Geosciences 345, 7-8, 327-335.

649 Lézine, A.-M., Watrin, J., Vincens, A., Hély, C., Contributors., 2009. Are modern pollen data 650 representative of west African vegetation? Review of Palaeobotany and Palynology 156, $651 \quad 265-276$.

652 Loehle, C., 2007. Predicting Pleistocene climate from vegetation in North America. Climate of 653 the Past 3, 109-118.

654 Maley, J., 1996. The African rain forest: main characteristics of changes in vegetation and 655 climate from the upper Cretaceous to the Quaternary. In: Essays on the Ecology of the 656 Guinea-Congo Rain Forest (Alexander IJ, Swaine MD, Watling R eds), pp. 31-73, 657 Proceedings of the Royal Society of Edinburgh 104B, Edinburgh.

658 Maley, J., Brenac, P., 1998. Vegetation dynamics, paleoenvironments abd climatic changes in 659 the forest of West Cameroon during the last 28,000 years. Rev., Paleobot. \& Palyno., 99, $660 \quad 157-188$.

661 Marchant R., Hooghiemstra H., 2004. Rapid environmental change in African and South 662 American tropics around 4000 years before present: a review. Earth Science Reviews 66, $663 \quad 217-260$.

664 Momo Solefack, M. C., 2009. Influence des activite's anthropiques sur la végétation du Mont 665 Oku (Cameroun). PhD Thesis, Université de Picardie, Amiens, France. 
666 New, M., Lister, D., Hulme, M., Makin, I., 2002. A high-resolution data set of surface climate 667 over global land areas. Climate research, 21, 1-25.

668 Novello, A., Lebatard, A. E., Moussa, A., Barboni, D., Sylvestre, F., Bourlès, D.L., Paillès, C., 669 Buchet, G., Decarreau, A., Duringer, P., Ghienne, J. F., Maley, J., Mazur, J.C., Roquin, C., 670 Schuster, M., Vignaud, P., 2015. Diatom, phytolith, and pollen records from a ${ }^{10} \mathrm{Be} /{ }^{9} \mathrm{Be}$ 671 dated lacustrine succession in the Chad basin: Insight on the Miocene-Pliocene 672

674 Prentice, I. C., Bondeau, A., Cramer, W., Harrison, S. P., Hickler, T., Lucht, W., Sitch, S., Smith, 675 B., Sykes, M. T., 2007. Dynamic global vegetation modelling: quantifying terrestrial 676 ecosystem responses to large-scale environmental change. In: Canadell, J. D., Pataki, E., 677 Pitelka, L. F. (eds.), Terrestrial Ecosystems in a Changing World. Springer-Verlag, Berlin, $678 \quad$ pp.175-192.

679 Prentice, I. C., Harrison, S. P., 2009. Ecosystem effects of CO2 concentration: evidence from $680 \quad$ past climates. Clim Past 5, 297-307.

681 Prentice, I. C., Jolly, D., BIOME 6000 participants., 2000. Mid-Holocene and glacial-maximum 682 vegetation geography of the northern continents and Africa. Journal of Biogeography 27, $683 \quad 507-519$.

684 Prentice, I. C., Sykes, M. T., Lautenschlager, M., Harrison, S. P., Denissenko, O., Bartlein, P. J., 685 1993. Modelling global vegetation pattern and terrestrial carbon storage at the last glacial 686 maximum. Global Ecol Biogeogr Lett, 3, 67-76.

687 Prentice, I. C., Webb, T., 1998. BIOME 6000: reconstructing global mid-Holocene vegetation 688 patterns from palaeoecological records. Journal of Biogeography 25, 6, 997-1005. 
689 Runge, J., 2002. Holocene landscape history and palaeohydrology evidenced by stable carbon 690 isotope (d13C) analysis of alluvial sediments in the Mbari valley $\left(5^{\circ} \mathrm{N} / 23^{\circ} \mathrm{E}\right)$, Central 691 African Republic. Catena 48, 67-87.

692 Sakata, T., Yokoi, Y., 2002. Analysis of the $\mathrm{O}_{2}$ dependency in leaf-level photosynthesis of two 693 Reynoutria japonica populations growing at different altitudes. Plant, Cell and 694 Environment, 25, 65-74.

695 Stager, J. C., Mayewski, P. A., Meeker, L. D., 2002. Cooling cycles, Heinrich event 1, and the 696 desiccation of Lake Victoria. Palaeogeography, Palaeoclimatology, Palaeococlogy 183, $697 \quad 169-178$.

698 Street-Perrot, F. A., Huang, Y. S., Perrott, R. A., Eglinton, G., Barker, P., Benkhelifa, L., 699 Harkness, D. D., Olago, D. O., 1997. Impact of lower atmospheric carbon dioxide on 700 tropical mountain ecosystems. Science 278, 5342, 1422-1426.

701 Terashima, I., Masuzawa, T., Ohba, H., Yokoi, Y., 1995. Is photosynthesis suppressed at higher 702 elevation due to low $\mathrm{CO}_{2}$ pressure. Ecology 76, 2663-2668.

703 Tierney, J. E., Russel, J. M., Huang, Y., Sinninghe Damsté, J. S., Hopmans, E. C., Cohen, A. S., 704 2008. Northern hemisphere controls on tropical southeast African climate during the past $705 \quad 60,000$ years. Science 322, 252-255.

706 Tierney, J.E., deMenocal, P.B. 2013. Abrupt shifts in Horn of Africa hydroclimate since the last 707 glacial maximum. Science 342, 843-846.

708 Troupin, G., 1982. Flore des plantes ligneuses du Rwanda. Institut national de la Recherche 709 scientifique, Butare747p.

710 Verschuren, D., Laird, K. R., Cumming, B. F., 2000. Rainfall and cdrought in equatorialeast 711 Africa during the past 1,100 years. Nature 403, 410-413. 
712 Vincens, A., Bremond, L., Brewer, S., Buchet, G., Dussouillez, P., 2006. Modern pollen-based

713 biome reconstructions in East Africa expanded to southern Tanzania. Review of

$714 \quad$ Palaeobotany and Palynology 140, 187-212.

715 Vincens, A., Buchet, G., Servant, M., ECOFIT Mbalang collaborators., 2010. Vegetation 716 response to the «African Humid Period» termination in Central Cameroon $\left(7^{\circ} \mathrm{N}\right)-$ new 717 pollen insight from lake Mbalang. Climate of the Past 6, 281-294.

718 Vincens, A., Lézine, A.-M., Buchet, G., Lewden, D., Le Thomas, A., Contributors., 2007.

719 African pollen database inventory of tree and shrub pollen types. Review of Palaeobotany 720 and Palynology 145, 135-141.

721 Vincens, A., Schwartz, D., Elenga, H., Reynaud-Farrera, I., Alexandre, A., Bertaux, J., Mariotti, 722 A., Martin, L., Meunier, J.-D., Nguetsop, F., Servant, M., Servant-Vildary, S., Wirrmann, 723 D., 1999. Forest response to climate changes in Atlantic Equatorial Africa during the last 7244000 years BP and inheritance on the modern landscapes. Journal of Biogeography 26, $725 \quad 879-885$.

726 Watrin, J., Lézine, A.-M., Hély, C., contributors., 2009. Plant migration and ecosystems at the 727 time of the "green Sahara", Comptes Rendus de l'Académie des Sciences - Géosciences, $728 \quad 341,656-670$.

729 Weldeab, S., Schneider, R.R., Kölling, M., Wefer, G., 2005. Holocene African droughts relate to $730 \quad$ eastern equatorial Atlantic cooling. Geology 33,981-984.

731 White, F., 1983. The vegetation of Africa. UNESCO, Paris, 384p.

732 Wu, H., Guiot, J., Brewer, S., Guo, Z., 2007a. Climatic changes in Eurasia and Africa at the last 733 glacial maximum and mid-Holocene: reconstruction from pollen data using inverse 734 vegetation modeling. Climate Dynamics 29, 211-229. 
735 Wu, H., Guiot, J., Brewer, S., Guo, Z., Peng C., 2007b. Dominant factors controlling glacial and interglacial variations in the treeline elevation in tropical Africa. Proceedings of the National Academy of Sciences of the United States of America 104, 23, 9720-9724. 